\title{
FORMING OF ENVIRONMENTALLY FRIENDLY TECHNOLOGIES OF PIG MANURE UTILISATION
}

\author{
Ekaterina Shalavina, Alexander Briukhanov, Roman Uvarov, Eduard Vasilev \\ Institute for Engineering and Environmental Problems in Agricultural Production - IEEP, Russia. \\ shalavinaev@mail.ru
}

\begin{abstract}
Research on BAT for intensive pig rearing showed that manure utilisation is the most sensitive and important element of any relevant technology. Formation of the manure utilisation technology includes the following steps: to identify the most applied practices by the decomposition method and block-hierarchical scheme; to create a mathematical model of pig manure utilisation, which includes characteristics of pig manure, utilisation techniques, machines and equipment for manure handling, and characteristics of produced organic fertilizer; to determine the most effective technology; to make a list of optional combinations of machines and equipment; to compare the obtained values in all combinations by the sound indicators using the Pareto method. The described procedure was tested on a pig complex with the complete pig rearing cycle with the average stock of 16,500 heads and manure humidity of $93 \%$. The most effective technology for this pig complex was found to be separation of manure into fractions with the subsequent processing of the solid fraction by passive composting and the biological treatment of the liquid fraction in an aeration tank and batch-type settling tanks. This technology features the following values of the main indicators: utilisation costs of one ton of pig manure with due account for nitrogen loss 1.99 thousand roubles per $t$, ecological and economic effect of the technology use and organic fertilizer application is 10463.6 thousand roubles per $t$ and economic efficiency of BAT introduction 3495.7 thousand roubles per t. The technology indicators may be slightly improved if composting is replaced by bio-fermentation in closed installations and if the hose injection systems are used for clarified liquid application. In this case the costs are lower by 5-7\% and the effectiveness of BAT introduction is lower by 2-3\%.
\end{abstract}

Keywords: environmental safety; nutrients loss; manure management; best available technique

\section{Introduction}

To supply the world population with required amount of food has always been one of the most urgent global problems. The Russian Federation is one of the few countries, which has favourable climatic conditions and sufficient resource capacity to produce high quality agricultural products. Having such a potential, the country is able not only to ensure the food security, but also to take the lead in the export of agricultural products.

The main way to realise the existing potential is to transfer to intensive production technologies with high economic and energy efficiency. At the same time, intensification of the industry leads to the increase of anthropogenic load on the environment, with the pig farming being the most telling example. Here, the competitive production is possible only on large-scale specialised complexes. Since 2004, the total number of pigs in Russia has been growing, while the number of small and medium pig farms drops (Fig. 1).

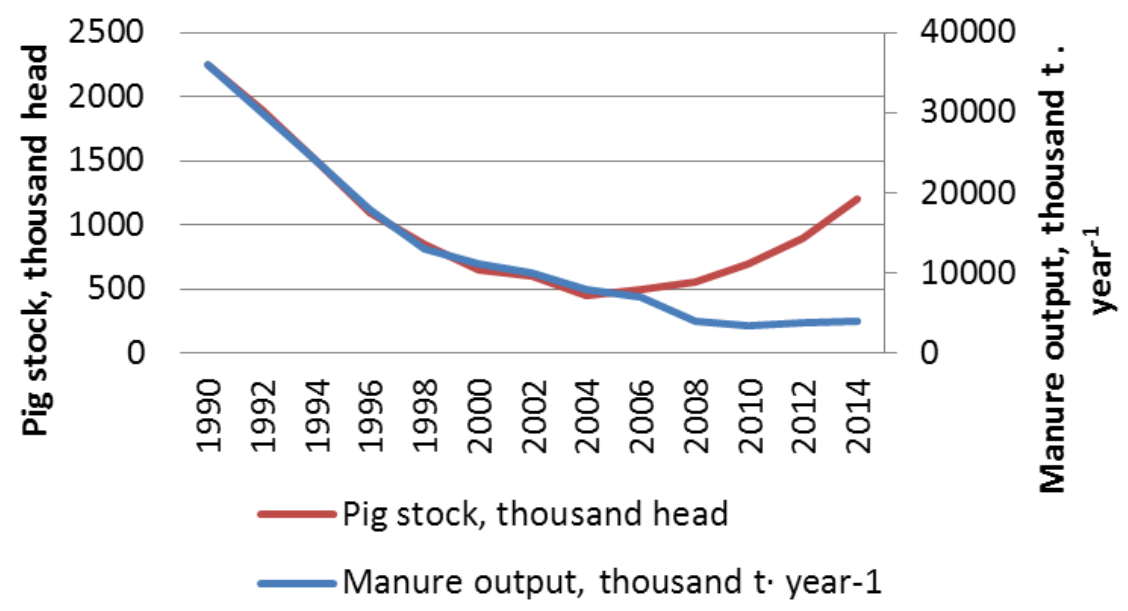

Fig. 1. Dynamics of pig stock and manure output in the Northwest Federal District 
The ecological component of large complexes' performance has significant disadvantages. Firstly, large amounts of liquid manure are produced. The introduction of up-to-date manure removal systems has notably decreased the specific output of manure owing to smaller entry of process water (Fig. 1). However, a complex with one-time housing of 100 thousand pigs produces above 365 thousand tons of liquid manure per year. Secondly, almost all functioning pig farms have no sufficient land for manure application; some pig complexes have no land at all for this purpose. These circumstances lead to higher risks of environmental pollution in the adjacent areas [1-5].

According to the survey, the many years' attention to the issues of food and environmental security in the advanced countries of the world resulted in the development of a highly efficient system of agricultural enterprise operation. The methodological basis of the system is the nutrient balance and application of recommended best available techniques (BAT). This system has economically justified costs, sustainable nature management, scientifically grounded technological regulations, including wastewater and atmospheric emissions treatment, and waste recycling. European BREF (Best Available Techniques Reference Document) is intended to be used as a prototype for similar Russian reference books, which are scheduled to be created for intensive pig and poultry rearing in 2017 [6;7].

Introduction of BAT principles requires the development of new methods to assess the impact of pig farms on the environment with due account for natural and climatic conditions of a particular region, and environmental and economic indicators of technologies.

Research on BAT for intensive pig rearing shows that manure utilisation is the most sensitive and important element of any relevant technology.

\section{Materials and methods}

Formation of pig manure utilisation technologies includes the following steps: to identify the most applied practices; to create a mathematical model of pig manure utilisation; to identify the most effective technology; to make a list of optional combinations of machines and equipment in this technology; to compare the obtained values in all combinations by the sound indicators using the Pareto method.

Decomposition method was applied to determine the most common technologies, and a hierarchical and block scheme of technology formation was created (Fig. 2).

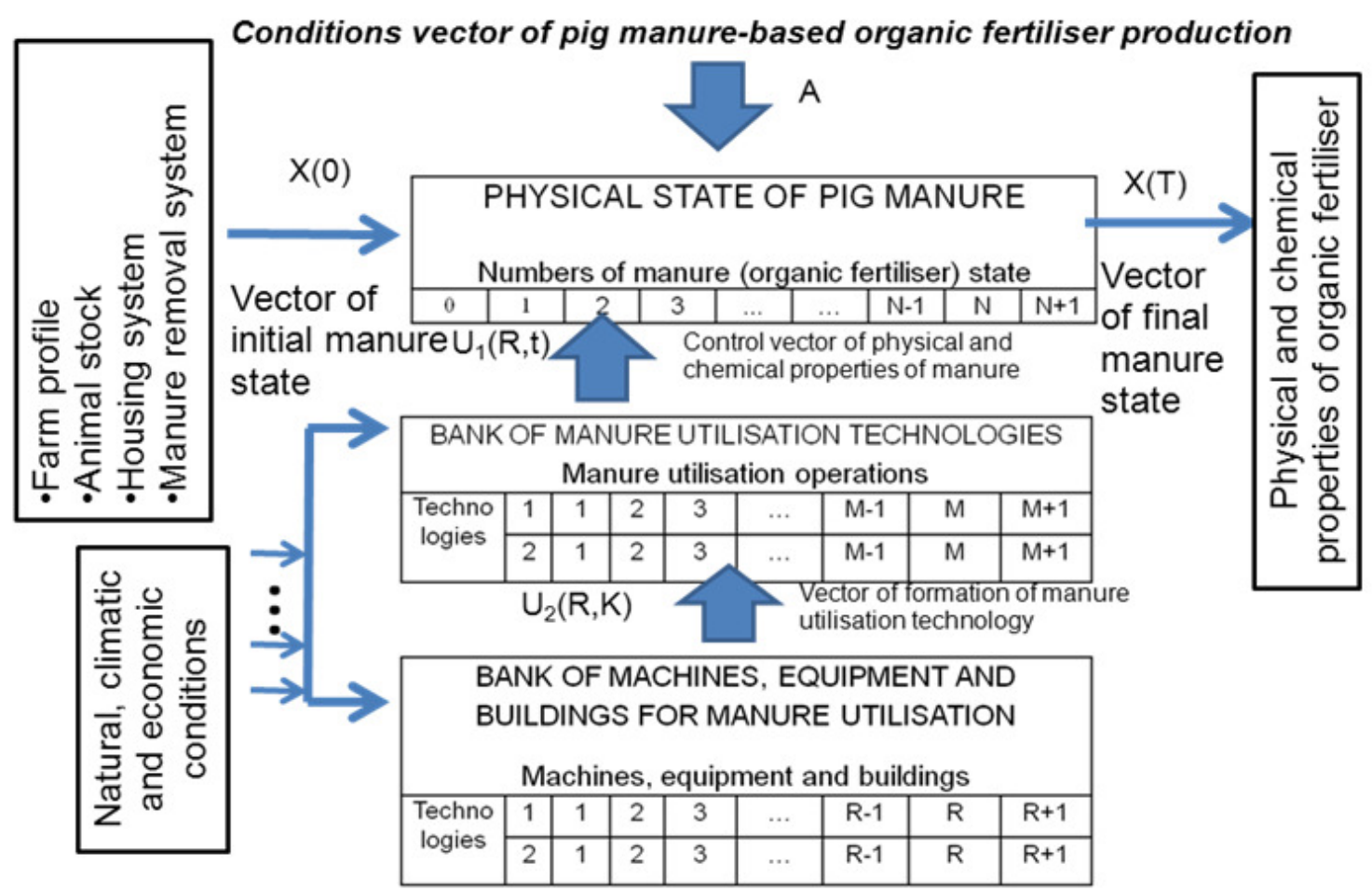

Fig. 2. General model structure for organic fertiliser production 
Vector of pig manure state develops in both the coordinate space and in a time interval, which is related to biochemical processes during manure utilisation. Physical and chemical parameters under the vector's transition from $\mathrm{X}(0)$ to $\mathrm{X}(\mathrm{T})$ were adopted as its main components.

The actual production processes occur in specific conditions under the influence of many factors, the main of which are those affecting the biochemical processes in the processed manure and produced organic fertilizers [8]. In the created model, the conditions vector of manure-based organic fertilizer production A affects the vector of manure state $\mathrm{X}$. The condition vector consists of many deterministic and random components. The nature of their effect significantly depends on the specific conditions of production and the animal housing system.

Pig manure processing technologies in other countries were reviewed. In Belgium, Canada, and Thailand, the multi-stage processing technology in aeration tanks with further disinfection of the solid fraction by sun drying prevails [9-11]. In the USA, Japan, Belarus and Australia, the technologies of multi-level processing with the use of flocculation and coagulation stations are in place [12-15]. Foreign technologies for processing liquid pig manure in the North-West Federal District of Russia are not applicable, because they do not meet the criterion of natural and climatic conditions.Taking into account the natural, climatic and production conditions of agricultural enterprises in the Northwest Federal District the following technologies for pig manure utilisation were considered in detail:

1. Long term manure maturing and application of liquid organic fertiliser.

2. Separation of manure into fractions (on a separator and a sedimentation tank with stop logs) with subsequent processing of solid fraction by passive composting and biological treatment of the liquid fraction in biological ponds.

3. Separation of manure into fractions (on a separator) with subsequent processing of the solid fraction by passive composting and biological treatment of the liquid fraction in an aeration tank with the use of flocculation facility.

4. Separation of manure into fractions (on a separator) with subsequent processing of the solid fraction by passive composting and biological treatment of the liquid fraction in an aeration tank with the use of coagulators.

5. Separation of manure into fractions (on a separator) with subsequent processing of the solid fraction by passive composting and biological treatment of the liquid fraction in an aeration tank with the use of batch-type settling tanks.

6. Separation of manure into fractions with subsequent processing of the solid fraction by composting and long-term maturing of the liquid fraction and application of liquid and solid organic fertilisers.

7. Separation of manure into fractions with subsequent processing of the solid fraction by biofermentation and long-term maturing of the liquid fraction and application of liquid and solid organic fertilisers.

8. Anaerobic processing with generation of electricity and heat (biogas production) and application of liquid organic fertilisers.

In general, the mathematical model of manure utilisation and organic fertiliser production may be shown as a ratio:

$$
X_{T}=A_{M} \cdot X_{O}+F_{1} \cdot U_{1} ; U_{1}=F_{2}\left(U_{2}\right) \cdot A,
$$

where $F_{1}, F_{2}-$ control vector of pig manure state;

$U_{1}$ - technology as control vector of pig manure state

$U_{2}$ - machines and equipment as control vector of pig manure state

$A$ - conditions vector for production of manure-based organic fertilisers

$X_{O}-$ initial value of manure state vector

$X_{T}$ - final value of manure state vector

$A_{M}$ - matrix of the vector of constant or variable values of factors influencing the production conditions of organic fertilisers is presented by the expression: 


$$
A_{M}=\left[\begin{array}{ccc}
a_{11} & \ldots & a_{1 n} \\
\ldots & \ldots & \ldots \\
a_{m 1} & \ldots & a_{m n}
\end{array}\right] .
$$

The following criteria were used in the integrated assessment of technology options of pig manure utilisation: utilization costs of one ton of pig manure with due account for nitrogen loss (thousand roubles per t); eco-economic effect of the technology use and organic fertiliser application (thousand roubles); and economic efficiency of BAT introduction (thousand roubles per t), which is calculated by the formula:

$$
E_{B A T}=\frac{Z_{o p e r}^{n+1}}{L^{n}-L^{n+1}}
$$

where $Z_{\text {oper }}^{n+1}$ - operational costs of the technology against the basic technology,

thousand roubles year ${ }^{-1}$;

$L^{n}$ - nitrogen emission in the basic technology, year $^{-1}$;

$L^{n+1}$ - nitrogen emission in the compared technology, $\mathrm{t}_{\text {year }}{ }^{-1}$;

Pareto optimisation method was used for a comparative assessment of the technologies.

A pig-rearing complex with the complete cycle having the average annual animal stock of 16,500 heads, manure humidity of $93 \%$, and $30 \mathrm{~km}$ transportation distance of organic fertilisers was chosen as a research object.

To determine the composition of machines and equipment for transportation and application of organic fertilisers the so-called single-loading technology with Belarus 3522 tractor + machine for liquid fertiliser application, which requires the minimal capital expenditures, was taken for all the technologies at the first stage of technology formation. The cost of one ton of diesel fuel was taken to be 30,000 roubles; the cost of electricity was taken to be five roubles per $\mathrm{kWh}$.

According to Technologies 1, 6, and 7 all produced manure is processed for organic fertilisers application; Technologies 2,3,4 and 5 are aimed to retain the maximum amount of suspended matter and nutrients in the solid fraction and to obtain the cleaned enough liquid to be discharged to the filtration fields or to be further purified in wastewater treatment facilities. Technology 8 allows to produce both an organic fertiliser and electricity and heat by burning the biogas. The biogas output per one ton of pig manure was taken to be $20 \mathrm{~m}^{3}$; the output of thermal and electric energy per one $\mathrm{m}^{3}$ of biogas was 2.3 and $2.1 \mathrm{kWh}$, respectively. It was assumed that all the thermal energy and about $50 \%$ of the electrical energy were consumed by the enterprise itself.

\section{Results and discussion}

Following the developed algorithms the main technical, economic and ecological indicators were determined (Table 1 and 2) and graphs of comparative characteristics of technologies were plotted (Fig. 3 and 4).

The data in Table 1 show that Technologies 3, 4, and 5 (production of organic fertilisers and cleaned liquid) have the best indicators of specific capital and operating costs owing to smaller number of equipment and operations related to organic fertiliser application. Technologies 6,7 , and 8 have better values of the eco-economic effect and BAT introduction effect compared to Technologies $1,2,3,4$, and 5. Moreover, Technology 8 has the best value of the eco-economic effect 16672 thousand roubles and BAT introduction effect -701.1 thousand roubles per t. However, due to high capital costs Technology 8 cannot be recommended for introduction. Today, most pig farms do not have cultivated land; and if available, the fields are at a considerable distance (in the case study $30 \mathrm{~km}$ ). So Technologies 6 and 7 become ineffective for businesses due to high capital and operating costs. In this situation, Technology 5 will be the most effective for the pig-breeding enterprise with the specified parameters, having the following values of the criteria: utilisation costs of one ton of pig manure with due regard for nitrogen loss (the so-called nitrogen retention factor) - 1.99 thousand 
roubles per t, eco-economic effect - 10463.6 thousand roubles per t and BAT introduction effect 3495.7 thousand roubles per $\mathrm{t}$.

Table 1

Technical, economic and ecological indicators of manure utilisation technologies (1-4)

\begin{tabular}{|c|c|c|c|c|c|}
\hline \multirow{2}{*}{ Indicators } & \multirow{2}{*}{ Unit } & \multicolumn{4}{|c|}{ Technologies } \\
\hline & & 1 & 2 & 3 & 4 \\
\hline Manure produced & $\mathrm{t} \cdot$ year $^{-1}$ & 54750 & 54750 & 54750 & 54750 \\
\hline $\begin{array}{c}\text { Annual output of organic } \\
\text { fertilisers, } \mathrm{t} \\
\text { liquid fertilisers; liquid/solid } \\
\text { organic fertilisers }\end{array}$ & $t \cdot$ year $^{-1}$ & 54750 & $39000 / 15750$ & $36500 / 18250$ & $35040 / 19710$ \\
\hline Capital costs & thousand RUB & 261800 & 122747 & 73667 & 75906 \\
\hline $\begin{array}{l}\text { Depreciation, maintenance, } \\
\text { repairs }\end{array}$ & $\begin{array}{l}\text { thousand } \\
\text { RUB } \cdot \text { year }^{-1}\end{array}$ & 14197 & 6046 & 4719 & 4882 \\
\hline \multirow{2}{*}{$\begin{array}{c}\text { Electric energy inputs per } \\
\text { year }\end{array}$} & $\mathrm{kWh} \cdot \mathrm{year}^{-1}$ & 49015 & 72343 & 506401 & 1003096 \\
\hline & thousand RUB & 245 & 362 & 2532 & 5015 \\
\hline \multirow{2}{*}{ Fuel inputs per year } & $\mathrm{t} \cdot$ year $^{-1}$ & 216 & 125 & 153 & 105 \\
\hline & thousand RUB & 6480 & 3751 & 4575 & 3162 \\
\hline \multirow{2}{*}{ Labour inputs per year } & man hours & 16300 & 7355 & 17155 & 12410 \\
\hline & thousand RUB & 1858 & 838 & 1956 & 1415 \\
\hline $\begin{array}{l}\text { Additional materials } \\
\text { (flocculent) }\end{array}$ & thousand RUB & - & - & 1560 & - \\
\hline Operational costs & thousand RUB & 22781 & 10998 & 15342 & 14474 \\
\hline Initial nitrogen mass & $\mathrm{t}$ & 186.2 & 186.2 & 186.2 & 186.2 \\
\hline Nitrogen retention factor & - & 0.38 & 0.39 & 0.40 & 0.40 \\
\hline $\begin{array}{c}\text { Manure utilisation costs with } \\
\text { due account for nitrogen } \\
\text { retention factor }\end{array}$ & $\begin{array}{l}\text { thousand } \\
\text { RUB } \cdot \mathrm{t}^{-1}\end{array}$ & 5.88 & 2.76 & 2.05 & 2.05 \\
\hline Yield increment & $\mathrm{t}$ & 1329.6 & 1071.0 & 1277.5 & 1379.7 \\
\hline Eco-economic effect & thousand RUB & 9972.3 & 8032.5 & 9581.3 & 10347.8 \\
\hline Nitrogen loss & $\mathrm{t}$ & 115.4 & 113.6 & 111.7 & 111.7 \\
\hline Reduction of emissions & $\mathrm{t}$ & - & 1.9 & 3.7 & 3.7 \\
\hline BAT introduction effect & $\begin{array}{l}\text { thousand } \\
\text { RUB } \cdot t^{-1}\end{array}$ & - & 5907.9 & 4120.9 & 3887.8 \\
\hline
\end{tabular}

Technical, economic and ecological indicators of manure utilisation technologies (5-8)

\begin{tabular}{|c|c|c|c|c|c|}
\hline \multirow{2}{*}{ Indicators } & \multirow{2}{*}{ Unit } & \multicolumn{4}{|c|}{ Technologies } \\
\hline & & 5 & 6 & 7 & 8 \\
\hline Manure produced & $\mathrm{t} \cdot$ year $^{-1}$ & 54750 & 54750 & 54750 & 54750 \\
\hline $\begin{array}{c}\text { Annual output of organic } \\
\text { fertilisers, } \mathrm{t} \\
\text { liquid fertilisers; liquid/solid } \\
\text { organic fertilisers }\end{array}$ & $t \cdot$ year $^{-1}$ & $\begin{array}{c}35100 / 1965 \\
0\end{array}$ & $50900 / 3850$ & $50900 / 3850$ & 54750 \\
\hline Capital costs & thousand RUB & 76253 & 125000 & 125200 & 531400 \\
\hline $\begin{array}{l}\text { Depreciation, maintenance, } \\
\text { repairs }\end{array}$ & $\begin{array}{l}\text { thousand } \\
\text { RUB } \cdot \text { year }^{-1}\end{array}$ & 4449 & 14275 & 14295 & 58055 \\
\hline \multirow{2}{*}{$\begin{array}{l}\text { Electric energy inputs per } \\
\text { year }\end{array}$} & $\mathrm{kWh} \cdot$ year $^{-1}$ & 1072073 & 26736 & 43526 & \\
\hline & thousand RUB & 4610 & 134 & 218 & \\
\hline \multirow{2}{*}{ Fuel inputs per year } & $t \cdot$ year $^{-1}$ & 106 & 239 & 243 & 239 \\
\hline & thousand RUB & 3182 & 7160 & 7292 & 7160 \\
\hline \multirow{2}{*}{ Labour inputs per year } & man hours & 11670 & 17030 & 17395 & 23235 \\
\hline & thousand RUB & 774 & 1941 & 1983 & 2649 \\
\hline $\begin{array}{l}\text { Additional materials } \\
\text { (flocculent) }\end{array}$ & thousand RUB & & - & - & - \\
\hline Operational costs & thousand RUB & 13015 & 23510 & 23787 & 67864 \\
\hline Initial nitrogen mass & $\mathrm{t}$ & 186.2 & 186.2 & 186.2 & 186.2 \\
\hline
\end{tabular}


Table 2 (continued)

\begin{tabular}{|c|c|c|c|c|c|}
\hline \multirow{2}{*}{ Indicators } & \multirow{2}{*}{ Unit } & \multicolumn{4}{|c|}{ Technologies } \\
\hline & & 5 & 6 & 7 & 8 \\
\hline Nitrogen retention factor & - & 0.40 & 0.45 & 0.52 & 0.50 \\
\hline $\begin{array}{l}\text { Manure utilisation costs with } \\
\text { due account for nitrogen } \\
\text { retention factor }\end{array}$ & $\begin{array}{l}\text { thousand } \\
\text { RUB } \cdot \mathrm{t}^{-1}\end{array}$ & 1.99 & 3.24 & 3.12 & 12.18 \\
\hline Yield increment & $\mathrm{t}$ & 1395.2 & 1681.6 & 1770.1 & 2222.9 \\
\hline Eco-economic effect & thousand RUB & 10463.6 & 12612.1 & 13275.8 & $16672 *$ \\
\hline Nitrogen loss & $\mathrm{t}$ & 111.7 & 102.4 & 89.4 & 18.6 \\
\hline Reduction of emissions & $\mathrm{t}$ & 3.7 & 13.0 & 26.1 & 96.8 \\
\hline BAT introduction effect & $\begin{array}{l}\text { thousand } \\
\text { RUB } \cdot \mathrm{t}^{-1}\end{array}$ & 3495.7 & 1804.3 & 912.8 & 701.1 \\
\hline
\end{tabular}

* additional electricity trading profit

a)

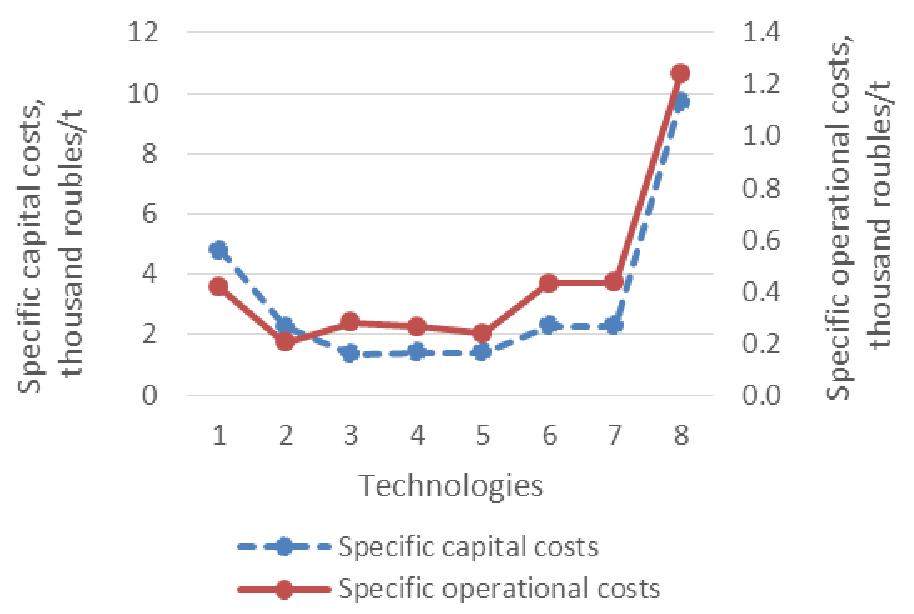

b)

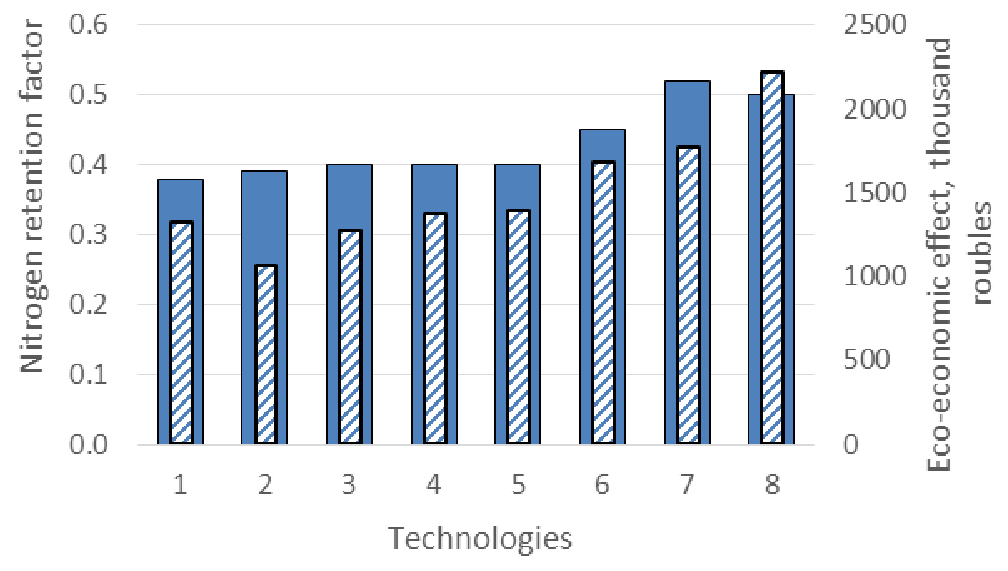

$\square$ Nitrogen retention factor $\quad \square$ Eco-economic effect

Fig. 3. Graphs of comparative characteristics of technologies: a - specific capital and operating costs for each technology; $b$ - values of nitrogen retention factor and eco-economic effect of each technology

At the second stage of technology formation the selected technology was considered in terms of the composition of machines, equipment and facilities as well as techniques for separate technological operations. To determine their effect on the eco-economic indicators, five options of the technology were designed. The source data for selecting the set of Pareto-optimal solutions are presented in Table 3. Option 1: settling tanks + composting pad + storing facility. Option 2: settling tanks + biofermenter. Option 3: settling tanks + bio-fermenter + liquid fertiliser application machine with mounted hoses. Option 4: settling tanks + bio-fermenter + liquid fertiliser application machine with injectors. Option 5: settling tanks + bio-fermenter + hose transportation system and sub-soil injection system. 
a)

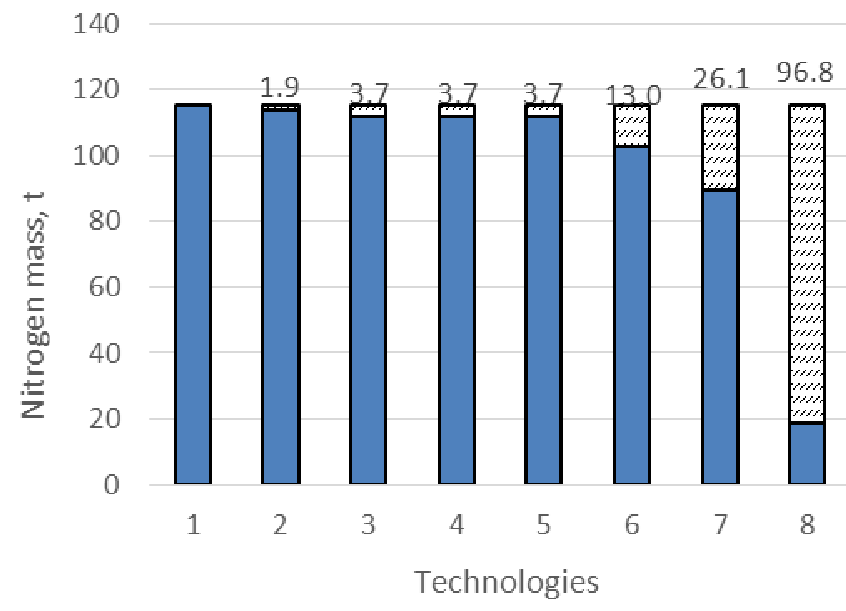

b)

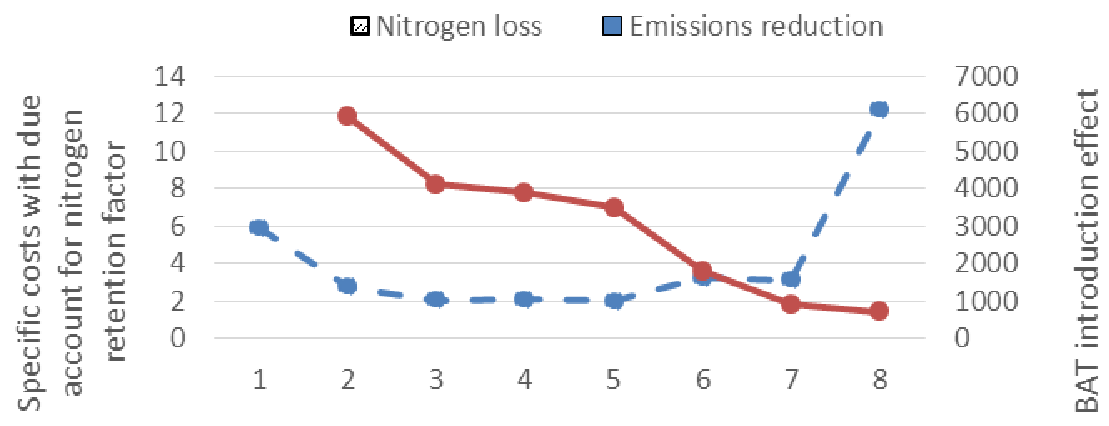

- Specific costs with due account for nitrogen retention factor

- BAT introduction effect

Fig. 4. Graphs of comparative characteristics of technologies: a - nitrogen loss and reduced emissions for each technology; b-eco-economic effect and specific manure utilisation costs with due account for nitrogen retention factor for each technology

Table 3

Selection of Pareto-optimal solutions

\begin{tabular}{|c|c|c|c|c|c|c|c|}
\hline \multirow{2}{*}{ Criteria } & \multirow{2}{*}{ Unit } & \multirow{2}{*}{$\begin{array}{c}\text { Direction } \\
\text { of } \\
\text { extremum }\end{array}$} & \multicolumn{5}{|c|}{ Options of Technology 5} \\
\hline & & & 1 & 2 & 3 & 4 & 5 \\
\hline $\begin{array}{c}\text { Utilisation } \\
\text { costs of one } \\
\text { ton of pig } \\
\text { manure with } \\
\text { due account } \\
\text { for nitrogen } \\
\text { loss }\end{array}$ & $\begin{array}{l}\text { thousand } \\
\text { RUB } \cdot t^{-1}\end{array}$ & $\min$ & 1.99 & 1.79 & 1.86 & 1.92 & 1.72 \\
\hline $\begin{array}{l}\text { Eco-economic } \\
\text { effect }\end{array}$ & $\begin{array}{l}\text { thousand } \\
\text { RUB }\end{array}$ & $\max$ & 10463.6 & 10650.0 & 11325.0 & 12112.5 & 12112.5 \\
\hline $\begin{array}{c}\text { BAT } \\
\text { introduction } \\
\text { effect }\end{array}$ & $\begin{array}{l}\text { thousand } \\
\text { RUB } \cdot t^{-1}\end{array}$ & $\min$ & 0.0 & 3873.1 & 2639.4 & 2015.8 & 1887.1 \\
\hline
\end{tabular}

The data in Table 2 clearly show that Option 5 of Technology 5 is the effective solution, which provides high environmental and economic indicators. The use of batch-type settling tanks for sedimentation, a bio-fermenter of closed type to process the solid manure, the hose system to transport the clarified liquid and its sub-soil injection provide the maximum value of the eco-economic effect 12112.5 thousand roubles, the minimal BAT introduction effect -1887.1 thousand roubles per $t$ and minimal values of specific costs of nitrogen retention -1.72 thousand roubles per $t$. 


\section{Conclusions}

1. Impact analysis of pig farms on the environment showed that the main source of hazardous emissions and effluents is manure due to its underuse and imperfect processing technologies in place.

2. The developed method and its algorithms allow to form the manure utilisation technology and to choose the option most adapted for specific farm conditions, using multi-criteria evaluation (rating).

3. The described procedure was tested on a pig complex with the complete pig rearing cycle with the average stock of 16,500 heads and manure humidity of $93 \%$.

4. The most effective technology for a pig-breeding farm with the specified parameters was found to be separation of manure into fractions with the subsequent processing of the solid fraction by passive composting and the biological treatment of the liquid fraction in an aeration tank and batch-type settling tanks. This technology has the following values of the main indicators: utilisation costs of one ton of pig manure with due account for nitrogen loss are 1.99 thousand roubles per $t$, eco- economic effect of the technology use and organic fertilizer application is 10463.6 thousand roubles per $t$ and economic efficiency of BAT introduction is 3495.7 thousand roubles per t. The technology indicators may be slightly improved if composting is replaced by bio-fermentation in closed installations and if the hose injection systems are used for clarified liquid application. In this case the costs are lower by $5-7 \%$ and the effectiveness of BAT introduction is lower by $2-3 \%$.

5. Considering the obtained results, which demonstrate $70 \%$ nitrogen retention in the pig manure utilisation technology, the total availability of nitrogen from organic fertilisers at North-western Federal District level will increase by $4 \%$, amounting to about 3,700 tons of nitrogen per year.

\section{References}

1. Kozlova N., Afanasyev A., Maximov N. Some aspects of emissions abatement from agriculture in the Russian Federation. Emissions from European Agriculture. 2005, p. 293-299. DOI: 10.3920/978-90-8686-540-6.

2. Еськов А.И. et. al. Справочная книга по производству и применению органических удобрений (Reference book on production and use of organic fertilisers). Vladimir, Russian Academy of Agricultural Sciences Publishers. 2005, 495 p. (in Russian).

3. Гриднев П.И., Мишуров Н.П. Технологии и технические средства для уборки и утилизации навоза в фермерских хозяйствах (Technologies, machines and equipment for removal and utilisation of manure on private farms). Moscow, Rosinformagrotech Publishers, 1996, 44 p. (in Russian).

4. Малаков Ю.Ф., Виноградова В.С., Соколов А.В., Новиков И.П. Биоконверсия органических отходов как способ повышения экологической чистоты производства и окружающей среды (Bioconversion of organic waste as a way to increase ecological cleanliness of production and environment). Journal of Moscow State Agroengineering University named after V.P. Goryachkin. 2007, №2, p.74-75. (in Russian).

5. Uvarov R., Briukhanov A., Shalavina E. Study results of mass and nutrient loss in technologies of different composting rate: case of bedding poultry manure. Engineering for Rural Development Proceedings. 2016. p. 851-857.

6. Integrated Pollution Prevention and Control (IPPC) Reference Document on Best Available Techniques for Intensive Rearing of Poultry and Pigs July 2003. [online][22.01.2017] Availabe at: https://www.ktbl.de/inhalte/themen/ueber-uns/ausgewaehlte-projekte/eu-project-bat-support/

7. Subbotin I.A., Briukhanov A.Yu., Uvarov R.A. Loss of nutrients at intensive processing of poultry manure. International Research Journal. 2016, № 1-3 (43), p. 41-42. DOI: 10.18454/IRJ.2016.43.132.

8. Завражнов А.И., Миронов В.В. Математическое моделирование биотехнологической системы производства органических удобрений (Mathematical modeling of biotechnological system of organic fertilisers production). Michurinsk. Michurinsk State Agrarian University Publishers, 2012. $151 \mathrm{p}$. 
9. Smet E., Debruyne J., Deckx J., Debooser S. Manure treatment according to the Trevi-concept. Proceedings 17th orum for Applied Biotechnology, 18-19 September 2003, Ghent, Belgium.

10. Optimized Gravitational Settling of Hog Manure Solids: Engineering and Design Study. Prepared by: DGH Engineering Ltd. 12 Aviation Boulevard St. Andrews, Manitoba R1A 3N5 October 2013.

11. Chantsavang S., Sinratchatanun C., Ayuwat K., Sirirote P. Application of effective microorganisms for swine waste treatment. Third International Conference on Kyusei Nature arming, Santa Barbara, 1993.

12. Singh P., Gamal el-Din M., Bromley D., Ikehata K. Alum Settling and Filtration Treatment of Liquid Swine Manure Transaction of ASABE. Amer. soc. of agriculture and biol. engineering. St. Joseph (Mich.). 2006. Vol. 49, N 5. P. 1487-1494.

13. HLTHMAN, volume 20, part 8, chapter 2. Waste water treatment.

14. Kavgarenja A.N., Niedziółka I., Tanaś W. Research of resources savings a way of recycling of manure drains. Journal of Research and Applications in Agricultural Engineering 2005. Vol. 0(1). P. 54-57.

15. Rabah F. Lecture 4: Sedimentation Islamic University of Gaza - Environmental Engineering Department. 